\title{
ELSŐ GENERÁCIÓS OKTATÓK PÁLYAKÉPE ÉS ÖNREFLEXIÓI ${ }^{+}$
}

\author{
BOCSI VERONIKA
}

Debreceni Egyetem Gyermeknevelési és Gyógypedagógiai Kar

\begin{abstract}
Vizsgálatunk során 11 első generációs oktató életútját és pályaképét tekintjük át, elemezzük az őket ért hátrányokat, a helyzetükből fakadó előnyöket, valamint igyekszünk feltárni az oktatási karrierjük főbb állomásait, továbbtanulásuk motivációit és pályaválasztásuk történetét. Az eredmények szerint az interjúalanyok tapasztalatai diverz mintákat mutatnak, tehát a hátrányok megélése nem általános jelenség, bár a megkérdezettek nagyobb részénél az erre utaló elemek megragadhatók. A hátrányok azokon a tudományterületeken jelentkeznek élesebben, ahol a kulturális tőke felhalmozása a szakmai identitás markánsabb részét képezi, vagy pedig az adott intézmény társadalmi háttere (mind oktatói, mind hallgatói) kedvező.
\end{abstract}

Kulcsszavakः első generációs oktatók, felsőoktatás, társadalmi mobilitás

The aim of this study is to recover the career and life path of 11 first-generation academics. We try to map their disadvantages or advantages - which are embedded in their social circumstances- motives of their further studies and the history of their career choices. The results have shown that their experiences are diverse. The experiencing of handicaps does not work in every case nevertheless these kinds of traces can be found in some forms by most of them. These handicaps seem to be more significant in the field of those disciplines in which cultural capital is rather the parts of the professional identities and professional socialisation or the prestige of the institution is high.

Keywords: first-generation academics, higher education, social mobility

\section{Bevezetés}

A z első generációs hallgatók kutatásának komoly felfutását tapasztalhatjuk a nemzetközi oktatásszociológiai szakirodalomban az ezredforduló óta (többek között: Terenzini et al. 1996; Oldfield 2012; Reay-Crozier-Clayton 2010).

Levelező szerző: Bocsi Veronika, Debreceni Egyetem Gyermeknevelési és Gyógypedagógiai Kar, 4220 Hajdúböszörmény, Désány István utca 1-9. E-mail: bocsiveron@gmail.com

+ A tanulmány a Bolyai János Kutatási ösztöndíj támogatásával készült. A tanulmány az Innovációs és Technológiai Minisztérium ÚNKP-20-05 kódszámú Új Nemzeti Kiválóság Programjának szakmai támogatásával készült. 
A kutatások fö kérdésköreit az eredményesség, a lemorzsolódás, az egyetemi integráció, a társadalmi mobilitás átélése, az identitás és a habitus átalakulása képezik. Az első generációs oktatókkal foglalkozó írások száma ugyanakkor a nemzetközi szakirodalomban is csekélyebb (például: Archer 2008; Bugaighis 2015; Dews-Law 1995). $\mathrm{A} z$ ő esetükben a befutott társadalmi mobilitási ív meredekebb, és az akadémiai világhoz történő adaptációt is egyértelműen sikeresnek tekinthetjük. Az első generációs oktatók egy éles váltással a habitusminták átadásának túlsó oldalán találják magukat, és egy olyan mezőbe kell beilleszkedniük, amelyről korábban kevés információval rendelkeztek, szabályait nem ismerték. Vizsgálatunk, ami egy nagyobb, más hangsúlyokkal bíró elemzés része, erre a folyamatra próbál rávilágítani pilotkutatás jelleggel.

\section{A $z$ első generációs lét fóbb jellemzői}

Elemzésünk elméleti kereteit zömmel a hallgatókra vonatkozó írások adják, hiszen az első generációs oktatókra vonatkozó elemzések nem állnak nagy számban a rendelkezésünkre. A campusra történő integráció, az itt átélt élmények és reakciók az oktatók életpályájának is szerves részét képezik.

A hallgatói elemzések talán legfontosabb csapásvonalát a nemzetközi szakirodalomban Bourdieu elméleteit alapul véve a különböző tőkefajtákkal való ellátottág és a habitus fogalom adja (például: Soria-Bultman 2014; Reay-Crozier-Clayton 2010), és itt mind a tőkefajták hozott hátrányait, mind pedig a campuson történő akkumuláció folyamatát vizsgálhatjuk. A hátrányok értelemszerủen a hozott tőkemennyiség alacsonyabb mértékében és az akkumuláció alacsonyabb fokában ragadhatók meg például a kulturális vagy a társadalmi tőke mentén, míg végzés után a gazdasági tőke csekélyebb felhalmozását figyelhetjük meg. A kutatások külön szála tárja fel az érintett diákok társas integrációját, ami a campuson belül és kívül is vizsgálható, illetve az oktatókhoz füződő kapcsolatok is fontosak (Rubin-Wright 2015; Lehmann 2012; Laemmli 2011; Christie 2016; Tiele et al. 2017) - különösen amiatt, hogy szoros kapcsolatban állnak a hallgatói eredményességgel. Itt a legtöbb vizsgálat egy alacsonyabb fokú integrációt, az extrakurrikuláris tevékenységekbe való ritkább részvételt, illetve az oktatókhoz füződő szálak gyengébb mintáit mutatja. Más kutatások az identitás változásának folyamatát tárják fel, a hibrid identitások kialakulását vagy teljes transzformációt (Reay-CrozierClayton 2010; Pearce-Down-Moore 2008), de fontos a családi környezet nevelésszociológiai elemzése is, ami sok esetben a szülők oktatáshoz füződő speciális attitűdjét jelenti (Cooper 2013). Itt jegyezzük meg, hogy az előbb felsorolt jellemzők beágyazottak a kulturális sajátosságokba (Xie-Reay 2019) és az egyetem szervezeti kereteibe is (Nimer 2020), s bizonyos doxáknak tekinthető kijelentéseket is cáfoltak már meg kutatások (pl. alacsonyabb karrieraspirációk - vö. Rabim-Azman 2010 és McCarron-Inkelas 2006 eltérő eredményeit).

Összességében azt mondhatjuk, hogy ezeknek a hallgatóknak ugyan alacsonyabb az esélye egy sikeres egyetemi karrierre, egyesek számára ez mégis elérhetővé válik. A szakirodalom őket nevezi első generációs oktatóknak. Arányuk a felsőoktatás rendszerszintű változásaiba, illetve a társadalmi mobilitás mértékébe is beágyazott. Az első inkriminált kutatások a 80-as években kezdődtek (Bugaighis 2015), és leginkább - a populáció alacsonyabb elemszáma miatt - kvalitatív technikák alkalmazásával készültek. A kvalitatív technikák használatát indokolta az is, hogy azok a jelenségek, amelyeknek a szűrőjén 
keresztül vagy felhasználásával ez a speciális élethelyzet megközelíthető, inkább ezekkel az eszközökkel írhatók le. Ilyen jelenség az identitás átalakulása (sok esetben kettős identitás kialakulása vagy akár a munkásosztálybeli identitás elvesztése), a nyelvhasználat, az öltözködési szokások, a habitus transzformációja és a bizonytalanság érzése. A leírások központi eleme az akadémiai világ és a kibocsátó közeg közötti distancia, annak megélése, az azzal való megküzdés és annak narratívája (Archer 2008; Dews-Law 1995). Az első generációs oktatók százalékos arányának bővülése összekapcsolódik az oktatók társadalmi rétegének heterogénebbé válásával is, akár a nemi, akár pedig az etnikai összetételt vizsgáljuk.

Magyarországon átfogó, az oktatók társadalmi hátterét leíró kutatások nem állnak rendelkezésünkre. ${ }^{1}$ Elszórva találunk kapcsolódó elemzéseket, mind például Bukodi (1998) munkáját, vagy a neveléstudomány területén fokozatot szerzettek vizsgálatát (Hrubos 2002; Kozma-Fényes-Tornyi 2007). Kozma és szerzötársai (2007) hangsúlyozzák, hogy a 47 fős mintájukba kerültek legnagyobb hányada második generációs értelmiségi, Bukodi (1998) pedig a kilencvenes években a „tudós társadalom” bezáródásáról ír, amely „speciális szelekciós mechanizmusok által” történik. Itt a szerző a foglalkozás státuszinkonzisztens helyzetére is utal: a pálya presztízse kimondottan magas (KSH 2018), miközben a bérezés alacsony, így annak választása egzisztenciális kockázatnak minősül. ${ }^{2}$ A nemzetközi szakirodalom által körbejárt olyan elemzési területek, mint az identitás átalakulása vagy a mobilitás narratívája a hazai elemzésekben még nem jelentek meg.

\section{Módszertan}

A tanulmányban feldolgozott interjúk egy átfogó, az értelmiségképzés és a felsőoktatás kapcsolatát vizsgáló kutatásnak a részei. A vizsgálat kvalitatív szála oktatói és hallgatói interjúkat tartalmaz. Az oktatói interjúkat félig strukturált formában, egyénileg vettük fel. A kérdésblokkok a következők voltak: az értelmiségi lét jellemzőinek meghatározása, a hallgatói bázis jellemzése, az egyetem szerepe az értelmiségképzésben és az intézmény kulturális klímájának jellemzői, az oktatói szerepek jellemzői, illetve első generációs oktatók esetén a lehetséges hátrányok és kompenzációs technikák leírása. Tanulmányunkban csak ez utóbbi kérdésblokkra adott válaszokat elemeztük.

A tanulmány megírásának pillanatában 21 oktatóval már rögzítettük a beszélgetést (összesen 30 oktatói interjút tervezünk). A 21 oktatóból 11 volt első generációs, azaz a szüleik nem voltak diplomások (bizonyos esetekben a nevelőszülők végzettségét használtuk). Jelen tanulmányunkban csak ezeket az interjúkat elemezzük.

$\mathrm{A} z$ interjúalanyok számát, az intézményük városának betűkódját és a vizsgált képzési területet az 1. táblázat mutatja be. Az interjúalanyok az intézményekben eltérő beosztásban dolgoztak: volt köztük egyetemi tanár és tanársegéd is, de a minta legnagyobb hányadát a docensek és adjunktusok adták. Az oktatói interjúk felvételét 2019 szeptemberében kezdtük. 18 interjút személyesen vettünk fel, ebből 17-et az adott intézményben és városban. 2020 tavaszától a járványhelyzetre való tekintettel a beszélgetéseket

\footnotetext{
A jelenség beágyazott a társadalmi mobilitás egészébe és jelentős oktatáspolitikai vonzatai is vannak. Ezeket a dimenziókat azonban a terjedelmi korlátok miatt nem fejtjük ki.

2 Köszönettel tartozunk Polónyi Istvánnak, hogy ráirányította a figyelmünket ezekre a vizsgálatokra.
} 
telefonon rögzítettük. Szakértői mintavételt alkalmaztunk, és ennek során igyekeztünk lefedni a különböző tudományterületeket és a felsőoktatás minél szélesebb spektrumát (települési szinten és presztízsben, illetve bekerült a mintába egy felekezeti intézmény két alannyal). Az 1. táblázat hét helyszínt tartalmaz, ugyanakkor a városok listája bővülni fog, illetve újabb tudományterületek beemelése is folyamatban van (egészségügyi, tisztán hitéleti, társadalomtudomány újabb szegmense). A táblázatban az első generációs oktatók számkódját félkövérrel jeleztük.

1. táblázat: Az interjúalanyok képzési terület és város szerint

\begin{tabular}{|c|c|c|c|c|c|c|c|}
\hline \multirow[t]{2}{*}{ Képzési terület } & \multicolumn{7}{|c|}{ Település (város betűkódja) } \\
\hline & A & B & $\mathrm{C}$ & $\mathrm{D}$ & $\mathrm{E}$ & $\mathrm{F}$ & G \\
\hline müvészeti & 1,2 & & & & & & \\
\hline orvosi & & $3 ., 4$ & & & & & \\
\hline agrártudományi & & & 5,6 & & & & \\
\hline jog & $7 ., 8$ & & & & & & \\
\hline müszaki & & 9. & 10. & & & & \\
\hline gazdaság & & & & $11 ., 12$ & & & \\
\hline bölcsészettudomány & & & & & $13,, 14$ & 15. & \\
\hline természettudomány & & & & & & & $16 ., 17$. \\
\hline $\begin{array}{l}\text { müszaki tudomány- } \\
\text { terület, informatika }\end{array}$ & 18., 19. & & & & & & \\
\hline $\begin{array}{l}\text { egyházi intézmény } \\
\text { hitéleti és világi } \\
\text { profillal }\end{array}$ & & $20 ., 21$ & & & & & \\
\hline
\end{tabular}

Megjegyzés: Az első generációs alanyokat félkövérrel jelöltük. (Forrás: Saját szerkesztés)

Az interjúkat kvalitatív tartalomelemzéssel dolgoztuk fel. Az elemzett területek a következők voltak: a családi háttér és a szülői attitűdök leírása, a pályaválasztás és tanulmányok bemutatása, illetve az önreflexió.

\section{Kutatási eredmények}

\section{Családi háttér és szülöi attitüdök}

A nemzetközi szakirodalom, mint korábban említettük, leginkább a tőkefajták segítségével igyekszik leírni az első generációs hallgatók és oktatók helyzetét. Jelen interjúalanyoknál az anyagi tőke hiányára történő utalások nem voltak jellemzők, ugyanakkor a kulturális tőke alacsonyabb szintje, illetve az ennek a helyzetnek a korrekciója a beszélgetések visszatérő elemei voltak. A kulturális tőkének mind az objektivált, tehát 
a tárgyakhoz kapcsolódó, mind pedig az inkorporált, azaz belsővé tett elemei hiányoztak - leginkább a bölcsészettudományi, társadalomtudományi és művészeti képzéseken tanítók esetén, valamint a magasabb presztízsű intézményekben. Két interjúalany helyzete annyiban volt speciális, hogy bár a szülők nem voltak diplomások, de az interjúalanyok elmondása alapján kultúrafogyasztóként kell őket elképzelni. Általánosságban a szülők a gyermekeik tanulási aspirációit támogatták (arra azonban volt példa, hogy az idősebb testvérét még nem), de legalábbis nem hátráltatták, ugyanakkor nem várták el a magas eredményességet és a továbbtanulást. Információkkal a szülők a gyermekeiket nem tudták segíteni a tanulási döntések során, és sok esetben nem volt, és jelenleg sincsen rálátásuk arra, ami a gyermekük tanulmányainak és munkájának tárgyát képezi.

„Vannak budapesti belvárosi barátaim, és amit ők kaptak, az teljesen más háttér, mint amit én kaptam. Tehát jártunk szinházba, de félévente egyszer, és nincs olyan szintü olvasottságom. Mert adtak a kezembe könyveket, de mégsem olyan minöségüeket." (13. alany)

„A mikor betegeskedtem, édesanyám nagyon sokat foglalkozott velem. Azt mondták, hogy ismételnem is kell, de anyukám mindig leült velem, és megkérdezte a tanároktól, hogy mi a feladat. És tovább is jutottam, mint a többiek. Ez sokat jelentett számomra. Ö nem értelmiségi, de az általános iskolás dolgokat még tudta." (7. alany)

„A testvérem elött nem volt kitaposott út, ezért volt vargabetüsebb az élete. Hiába volt általános iskolában a legjobb tanuló, apa megmakacsolta magát, bogy csak a szakma. Na, most (város neve)-ban mi van? Óvónőképzö. Tehát a nővérem nem mehetett gimnáziumba. Toronymagasan elvégezte, de nem vették fel az egyetemre, mert nem volt meg az az alapmüveltsége." (1. alany)

„Én ott középiskolában a bülye vidéki voltam, aki egyszerü ember, ök meg a nagyvárosban éltek. Aztán kiderült, hogy mindegyik faluból beköltözött szülök gyereke." (19. alany)

„Az elörejutás vágya megvolt a családban. A nagyapám a saját anyámmal együtt érettségizett. De hát azok más idők voltak, munkába kellett állni. De attól még a maguk módján kultúrafogyasztók voltak." (2. alany).

"Arra emlékszem, hogy nyolc évesen hordtam haza a könyvtári könyveket. Nem tudom, hogy egy pszichológus ebhez mit szólna, de szerintem ez nekem picit menekülés volt. A körülmények a családunkban nem voltak túl rózsásak, mint erre már tettem utalást, és én a könyvekbe meg a fantáziákba menekültem." (20. alany)

A megkérdezettek többsége, mint már említettük, megnevezte azokat a hátrányokat, amelyekkel meg kellett küzdenie az életpályája során. A kulturális tőke különféle formáira már utaltunk, azonban fontos elemként jelenik meg az egyetem látens működéséről alkotott hiányos kép és az oktatói rekrutációval kapcsolatos ismeretek hiánya - az érintettek egy részének semmilyen információja nem volt a doktori képzésről (néha még a létéről sem). A kompenzáció módja a kulturális tőke esetében a tudatos és pótló fogyasztás (könyvolvasás, színházba járás), illetve több esetben megjelent az átalakuló kapcsolathálóban folyó diskurzusok hatása. A korábbi baráti kapcsolathálók fenntartása kevésbé jellemző.

$\mathrm{A} z$ első generációs lét előnyeként azt a sajátos világlátást emelhetjük ki, ami a társadalom mind a két szegmensének a megértését biztosítja. Ugyanakkor a megfutott mobilitás értelemszerủen valamilyen módon elvágja az alanyokat a kibocsátó közegtől. Az egyik interjúalany narratívájában egyértelmű előnyként fogalmazódik meg az, hogy 
a megtett életpálya csak a saját munkájának az eredménye, hiszen mások ebben nem tudták támogatni.

„Mivel soha nem gondoltam bele abba, hogy milyen hátrányom származik ebböl, ezért nem binném, hogy lett volna hátránya (a származásomnak). Mezögazdasági szakközépiskolába jártam, ott nagyon ritka volt az, hogy diplomások lennének a szülök. Föiskolán megint ez volt a belyzet." (5. alany)

"Amikor szinjátszást tanultam, ott volt pár szinjátszó társam, akik második vagy harmadik generációs értelmiségiek voltak. Ott szembesültem vele, hogy én, bár mindig nagyon szorgalmasan olvastam, meg vásároltam is könyveket, de az én általános müveltségem semmi ezekhez a gyerekekhez képest. És kérdezgettem is öket, hogy te hogy tudsz ennyi mindenröl? (20. alany)

„Szerintem az elönye az ennek a belyzetnek, hogy mind a két világnak a részeseként tartom számon magamat [...]. Látom mind a két világnak a pozitívumait meg a negatívumait is. Részesültem a nem értelmiségi világból, és láttam, hogy annak is vannak impulzusai." (7. alany)

\section{Pályaválasztás és tanulmányok}

A tanulmányi előmenetellel kapcsolatos legfontosabb sajátosság az, hogy a karrierépítés „királyi útja” ritkán fordul elő. A legtöbb interjúalany élete kerülőutakkal, vargabetűkkel teli - volt, akinek a PhD képzését részben a kötelező katonaság kikerülése inspirálta. Gyakoriak voltak a tudományterületi váltások is. A szülők a képzések közötti választást segíteni értelemszerűen nem tudták, így a döntéseket az alanyok önállóan hozták meg. Felvételijük időpontja sok esetben még az expanzió előtti időszakra esett, amikor is a bekerülés esélye alacsonyabb volt - azt azonban látni kell, hogy gyakran második vagy harmadik körben sikerült bejutniuk a kiválasztott képzésekre -, majd sok esetben még újabb tudományterületi váltások következtek. A PhD megkezdése előtt szintén láthatunk kerülőutakat, amelyekről az egyéni kapcsolathálók egyes szereplői (korábbi témavezetők, élettársak stb.) „húzzák vissza” a felsőoktatásba a későbbi oktatókat.

„Hogy mit szóltak, amikor bejelentettem, hogy zongorista akarok lenni? Nem mondom, hogy kitörö örömmel fogadták. Tudták, hogy vannak eredményeim [...]. Országos társadalomkutató versenyt nyertünk, és az volt a nyereményünk, hogy bármelyik középiskolába felvettek volna. Kivéve a müvészetit. És mit mondtam én? Megyek, felvételizek a müvészetibe." (1. alany)

„Hármas-négyes tanuló voltam. Felsőben 3,6 is volt az átlagom. Semmi különlegesség. Annyi, hogy voltak ilyen heppjeim, hogy hetedikben a kémiát megszerettem, és elmebeteg módon a szabadidömben kémia könyveket olvasgattam. Ott már lebetett érezni, hogy baj van velem." (19. alany)

"A rokonságom akkor nézett elöször bülyének, amikor otthagytam a föiskolát, és elkezdtem szinházat csinálni. Nagymamám nem akart szóba állni velem. Édesanyám sem. És aztán, mikor kitaláltam magamnak a nyelvészetet, akkor meg csak néztek, hogy ezt miért kell? [...] És amikor a doktoriba jelentkeztem, szegény édesanyám, már nem sokáig élt, és még a balálos ágyán is kérdezte, hogy ez tulajdonképpen mire jó? Miért csinálod?" (20. alany)

$\mathrm{A} z$ egyetemi karrier felépítésében nagyon nagy szerepet kapnak a témavezetők (akár szakdolgozati, akár PhD szinten). Több interjúban is felidézték az alanyok a téma- 
vezetők hatását az egyéni döntésekre - ez azért is különösen fontos, mert az alanyok nem, vagy alig rendelkeztek információkkal arról, hogy miként is lehet felépíteni egy egyetemi karriert. Az oktatói és tanári kapcsolatok fontosságára az első generációs hallgatók kapcsán több tanulmány hívja fel a figyelmet (Laemmli 2011; Lightweis 2014; Tinto 1999).

"Már gimnáziumban is volt kémia tanárom, aki nagyon támogatott, és beszervezett bemutatókra, mikor jöttek az általános iskolások [...]. Az egyetemen a kisérletezés vonzott, és nagyon hamar bekerültem diákkörösnek. [...] A témavezetömnek sokat köszönhetek, mert nagyon támogatott. Ö is elsö generációs értelmiségi egyébként, és mondta, hogy van lehetöség ott maradni, meg kell csinálni a PbD-t. De le kell menni a boncterembe, el kell kezdeni megtanulni, aztán oktatni. Akkor én ezt megtettem, bár nem volt könnyü." (3. alany)

"Nekem a fövárosba bekerülni Phd-zni a ...-i intézetbe, az felért egy kulturális sokkal. Azért mert (város neve) közege, ez a szellemi és kulturális közeg attól fényévekre van. Onnan ránézni erre... És amit látok, és ezt most nem lenézésböl mondom, mert én is ennek a részese vagyok... az olyan provinciális." (8. alany)

„A szakdolgozat témája jó volt, kutattunk, nagyon tetszett. Valabol megláttam, hogy lebet PhD-zni, de nem nagyon tudtam én, hogy ez mit jelent. Próbáltam utánajárni, és feltettem pár kérdést a témavezetömnek. Én úgy általában akartam kérdezgetni, de ö meg azt bitte, hogy én mindenképpen hozzá akarok menni. Életem legjobb választása volt egyébként, mert amúgy azt sem tudtam, hogy mi a témája." (19. alany)

\section{Önreflexió}

A z interjúalanyok egy részénél egy választóvonal válik láthatóvá, ami az alany saját világát, gondolkodását és a többgenerációs értelmiségi kollégák világát egymástól elválasztja, és ez több esetben egy földrajzi (Budapest és a többi város közötti) dimenzióval egészül ki. Az első generációs értelmiségi lét alacsonyabb önértékeléssel is társulhat („nem vagyok annyira patkolt, mint mások" 20. interjúalany), és előhívhatja a frusztráció érzését („abszolút frusztráció nekem az értelmiséghez tartozás” 13. alany). Azoknak az oktatóknak az esetében, akik származásukhoz kapcsolódó hátrányt nem tudtak megnevezni, értelemszerüen ezek a motívumok hiányoznak. Két interjúban köszönt vissza az a törekvés, hogy saját megélt hátrányaik miatt igyekeznek maguk is olyan hallgatóknak segíteni, akik hasonló szituációban vannak, tehát szülői támogatás nélkül, alacsonyabb kulturális tőkével kerültek be a felsőoktatásba (vö. Dews-Law 1995). Más interjúalanyok nagyobb szociális érzékenységüket, a társadalmi folyamatok több szempontból való átlátását jelölték meg a helyzetük pozitív hozadékaként.

„Az zárkóztatott fel valamennyire, hogy értelmiségi körökben mozgok. Elkapok beszélgetésfoszlányokat, vagy beszélgetnek valamiröl, és akkor jelen vagyok, majd utánanézek ennek. Próbálom felvenni a fonalat." (13. alany)

„Ez bennem is megvolt, hogy neki lehet vágni egyedül (az életnek). Nem gondoltam, hogy ott maradok (otthon). Én ettöl soha nem riadtam vissza, hogy olyat csináljak, amit még nem láttam. És, hát, elsö generációs vagyok, szóval nem tudtam, mire vállalkozok. [...] Hogy milyen érzés hazamenni? Jó amúgy. Egy dolog van, ami érdekes. Mikor megkérdezik, hogy mit tanitok. Statisztikát. Úristen! Erre ez a reakció, mert el sem tudják képzelni, hogy hogyan 
lehet statisztikát tanitani. De mindig mondják, hogy jó esze volt, és jól tette, nagyon ügyes. Ezek a reakciók megvannak, de nyilván furcsa." (12. alany)

„Elsö körben ez nagyon rosszul érintett (a lemaradásom). Önértékelési problémáim voltak emiatt. Sokáig azt gondoltam, hogy ezt képtelenség behozni, de már azt gondolom, hogy ezt nem is kell behozni. Együtt kell tudni élni azzal, hogy te ez a fajta értelmiségi vagy [... ]. Így kell együtt haladnom a többivel. Már korábban rá kellett volna jönnöm, hogy ezt fel lehet vállalni, hogy gyerekek, én a magam erejéböl eddig jutottam." (20. alany)

\section{Limitációk}

A kutatás limitációját egyrészt a mintavétel és a minta elemszáma képezi. Bár igyekeztünk lefedni az tudományterületek és a helyszínek minél szélesebb spektrumát, az ebből eredeztethető torzító hatás nem zárható ki. A limitációk másik szála ahhoz kapcsolható, hogy az első generációs oktatók nem képezték a minta egészét, így jelenleg 11 első generációs oktatóval készült interjú áll a rendelkezésünkre. Fontos hangsúlyozni, hogy jelen téma nem képezte a tágabb vizsgálat fó fókuszát.

\section{Összegzés}

Vizsgálatunknak a célja az volt, hogy ráirányítsa a figyelmet egy hazai és nemzetközi viszonylatban kevéssé vagy alig kutatott témára, az első generációs oktatók helyzetére. A z elemzéshez a nemzetközi kvalitatív vizsgálatok főbb csomópontjait használtuk fel, és az elméleti keretekben bemutatott sajátosságokhoz hasonló életpálya-elemeket találtunk. Ki tudtuk mutatni az interjúalanyok többségénél a hátrány vagy a disszonancia érzését, illetve a külső segítségek és fogódzók fontosságát a karrierek felépítésében. Láthattuk az életpályák vargabetűit, és azt, hogy az ún. „királyi út”, ami töréspontok nélkül vezet az egyetemi-föiskolai oktatói léthez, az említett hátrányok és a felsőoktatással kapcsolatos információk hiánya miatt ritkábban valósul meg. Az így kapott adatok érvényessége ugyan az előbb felsorolt limitációk miatt korlátozott, de reményeink szerint képletesen bemutatják a társadalmi mobilitás megélésének folyamatát, az egyetemek látens működését, és azt az érdekes, kettősségekbe ágyazott társadalmi pozíciót, ami az első generációs oktatókat jellemzi.

\section{IRODALOM}

Archer, L. (2008) Younger Academics' Constructions of 'Authenticity', 'Success' and Professional Identity. Studies in Higher Education, Vol. 33. No. 4. pp. 385-403.

Bugaighis, T. E. (2015) I Am Just Like My Students: Working Class Academics at a Community College. Thesis. USA (PA), Lehigh University.

Buкodi E. (1998) A tudományos elit anyagi és mobilitási viszonyai. In: Kolosı T., Tótн I. Gy. \& Vukovics Gy. (eds) Társadalmi Riport 1998. Budapest: TÁRKI, pp. 200-215.

Christie, F. (2016) Career Guidance and Social Mobility in UK Higher Education. British Journal of Guidance and Counselling, Vol. 44. No. 1. pp. 72-85.

Cooper, L. (2013) Women in Higher Education: Perspectives of Middle-Class, Mother Daughter Dyads. Gender and Education, Vol. 25. No. 5. pp. 624-639. 
Dews, C. L. B. \& Law, C. L. (1995) The Making of Working Class Academics: "This Fine Place So Far from Home". USA (PA), Temple University Press.

Нrubos I. (2002) Az oktatást kutató diplomás. Educatio, Vol. 11. No. 2. pp. 253-265.

Kozma T., Fényes H. \& Torny Z Zs. (2007) Negyvenheten. Gyorskép a neveléstudományi oktatókról és kutatókról. Educatio, Vol. 16. No. 3. pp. 418-433.

Központi Statisztikai Hivatal (KSH) (2018) Mikrocenzus 2016. A foglalkozások presztízse. Budapest, Központi Statisztikai Hivatal.

Laemmli, T. (2011) "Getting Educated": Working Class and First Generation Students and the Extra-curriculum. Sociology of Honour Projects. Paper 32. https://digitalcommons. macalester.edu/cgi/viewcontent.cgi?article $=1034 \&$ context $=$ soci_honors [Letöltve: 2019. 03. 10.]

Lehmann, W. (2012) Extra-credential Experiences and Social Closure: Working Class Students at University. British Educational Research Journal, Vol. 38. No. 2. pp. 203-218.

Lightweis, S. (2014) The Challenges, Persistence, and Success of White, Working-Class, First-Generation College Students. College Student Journal, Vol. 48. No. 3. pp. 461-467.

McCarron, G. P. \& Inkelas, K. K. (2006) The Gap between Educational Aspirations and Attainment for First-Generation College Students and the Role of Parental Involvement. Journal of College Student Development, Vol. 47. pp. 534-549. https://doi.org/10.1353/ csd.2006.0059

Nimer, M. (2020) Beyond Social Mobility: Habitus and Responses to Changing 'Condition of Existence' among University Scholarship Students. Sociological Research Online. First published on April 2, 2020. https://doi.org/10.1177/1360780420911380

Oldfield, K. (2012) Still Humble and Hopeful: Two More Recommendations on Welcoming First Generation Poor and Working-Class Students to College. About Campus, (December 14, 2012). About Campus, November-December 2012. Available at SSRN: https://ssrn.com/abstract=3018759 [Letöltve: 2020. 06. 28.]

Pearce, J., Down, B., \& Moore, E. (2008) Social Class, Identity and the Good Student: Negotiating University Culture. Australian Journal of Education, Vol. 52. No. 3. pp. 257271. https://doi.org/10.1177/000494410805200304

Raнim, A. H. A. \& Azman, N. (2010) Educational Aspirations among First-generation Students and their Parental Influence towards Pursuing Tertiary Education.

Procedia-Social and Behavioral Sciences, Vol. 7. pp. 414-418, https://doi.org/10.1016/j. sbspro.2010.10.056

Reay, D., Crozier, G. \& Clayton, J. (2010) 'Fitting in' or 'standing out': Working class students in UK higher education. British Educational Research Journal, Vol. 36. No. 1. pp. 107-124.

Rubin, M. \& Wright, C. L. (2017) Time and Money Explain Social Class Differences in Students' Social Integration at University. Studies in Higher Education, Vol. 42. No. 2. pp. 315-330. https://doi.org/10.1080/03075079.2015.1045481

Soria, K. \& Bultman, M. (2014) Supporting Working-Class Students in Higher Education. NACADA Journal, Vol. 34. No. 2. pp. 51-62.

Terenzini, P. T., Springer, L., Yaeger, P. M., Pascarella, E. T. \& Nora, A. (1996) First-generation College Students: Characteristics, Experiences, and Cognitive Development. Research in Higher Education, Vol. 37. No. 1. pp. 1-22.

Tiele, T., Pope, D., Singletin, A., Snape, D. \& Stanistreet, D. (2017) Experience of Disadvantage: The Influence Of Identity on Engagement in Working Class Students' Educational Trajectories to an Elite University. British Educational Research Journal, Vol. 43. No. 1. pp. 49-67. 
Tinto, V. (2002) Taking Student Retention Seriously: Moving beyond Add-ons. NACADA Journal, Vol. 19. No. 2. pp. 5-10.

XIE, A. \& Reay, D. (2019) Successful Rural Students in China's Elite Universities: Habitus Transformation and Inevitable Hidden Injuries? Higher Education, First published on October 23, 2020. https://doi.org/10.1007/s10734-019-00462-9

A cikk a Creative Commons Attribution 4.0 International License (https://creativecommons.org/licenses/ by/4.0/) feltételei szerint publikált Open Access közlemény, melynek szellemében a cikk bármilyen médiumban szabadon felhasználható, megosztható és újraközölhető, feltéve, hogy az eredeti szerző és a közlés helye, illetve a CC License linkje és az esetlegesen végrehajtott módosítások feltüntetésre kerülnek. (SID_1) 